\title{
Extraction of Lineament Density Analysis from ASTER DEM for Determine the Vein Direction
}

\author{
$1^{\text {st }}$ Ignatius Adi Prabowo $1,2^{\text {nd }}$ Okki Verdiansyah ${ }^{2}, 3^{\text {rd }}$ Raras Prabowo $^{3}$ \\ adi.prabowo@sttnas.ac.id ${ }^{1}$, raraskolibri@gmail.com ${ }^{2}$ \\ Geological Engineering Department, Institut Teknologi Nasional Yogyakarta, Indonesia
}

\begin{abstract}
The research area in Pacitan Regency is one area that has the potential for hydrothermal mineralization in the form of altered rocks and quartz veins formed in Oligocene-Miocene. Magmatic rocks and lineament can be used as an early indication of changes and mineralization. This study aims to identify the dominant direction of vein surface using the Lineament Density Analysis (LDA) method. Shade-relief images created from the ASTER Digital Elevation Model (DEM) help identify alignments in various reliefs and topography. This method can improve straightness in various orientations by simulating topographic lighting in various light directions. The lineament map analysis results that were extracted automatically and manually showed that the direction was NW-SE, N-S, and NE-SW. The results of analysis of field data samples indicate that the alignment direction NW-SE, N-S, and W-E. LDA application to determine the direction of the structure proved to be possible and can be used.
\end{abstract}

Keywords : Lineament Density Analisys, ASTER DEM, Vein Direction

\section{Introduction}

Javanese metal mineral deposits, are part of the Sunda-Banda magmatism. Developed mineralization is associated with arc magmatism hydrothermal systems, such as in the Seven Hills complex (Banyuwangi) with the type of High Sulfidation and Porphyry $\mathrm{Cu}-\mathrm{Au}$ mineralization, and in the Selogiri complex with the Porphyry Au-Cu mineralization type.

Geological research in Pacitan has been carried out, especially in the fields of alteration and mineralization. Lineament that is expressed in satellite images from remote sensing results can be observed and mapped. This alignment can reflect the geological structure (Herlambang, RF, and Novranza, Kms, 2016)[1]. This study aims to identify the dominant direction of vein surface using the Lineament Density Analysis (LDA) method.

DEM is digital elevation data which records topographic surface expressions. The topographic attribute can be extracted from digital elevation data by applying a special computer algorithm.

The term "straightness" is one of the most commonly used terms in geology. A line is a large linear surface on a planet, as a fault line or fracture line.

The location of the LDA study was carried out in the area of Pacitan Regency and its surroundings, East Java Province. The research area covers the regional area of Pacitan (Figure 1) 


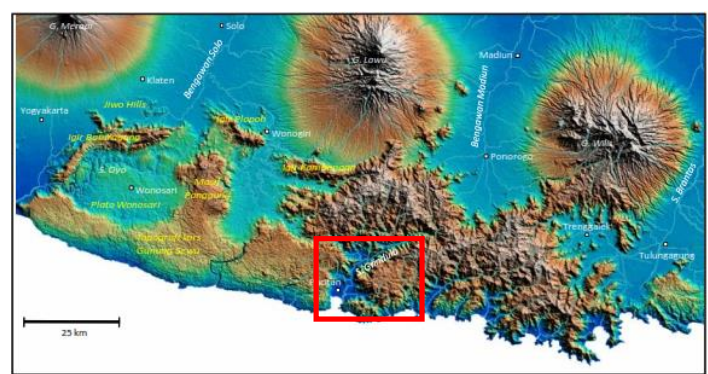

Figure 1. Location of study area Lineament Density Analysis.

Pacitan area is a hilly area with high topography and steep, only a few places in the form of plains. In general the Pacitan area is composed of clastic sedimentary rocks, volcanic rocks and breakthrough rocks (Samodra et al., 1992)[2].

\section{METHODS}

The method used is a quantitative method that is combined with the search for high-density lineanment zone values that are semi-automatic by using computer software and interpreted qualitatively with other geological data.

Lineament Density Analysis in this study uses Digital Elevation Model (DEM) data from ASTER $90 \mathrm{~m}$, which is then analyzed for line density density, using computer softwere to distinguish patterns formed by differences in morphometry.

The process of analysis is a desktop study which is then supplemented with field checking data, following the steps in (Figure 2):

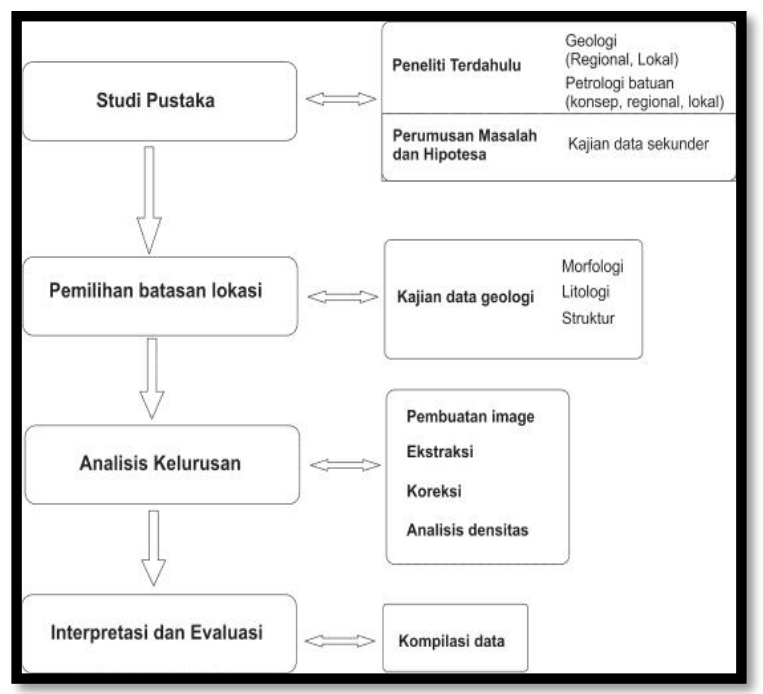

Fig. 2. Flowchart of research (Verdiansyah, O., and Hartono, H., G., 2018)[3].

In this study, secondary data used are: 
a. Regional geological data.

b. Geological data, geological structures, volcanoes of the Pacitan region and its surroundings by several previous researchers

c. DEM digital data from Aster-90 m.

Lineament extraction step is obtained automatically using the PCI Geomatica software. The extraction process (Line Extraction) uses the [LINE] algorithm on PCI Geomatica, by entering the parameters used by (Abdullah, et. al, 2010) [4] (Table 1).

Table 1. Use of parameter values in Lineanment extraction using PCI-Geomatica 15 software (Abdullah, et. al, 2010)[4]

\begin{tabular}{ccc}
\hline Name & Description & Values \\
\hline RADI & Radius of filter in pixels & 12 \\
GTHR & Threshold for edge gradient & 90 \\
LTHR & Threshold for curve length & 30 \\
FTHR & Threshold for line fitting error & 10 \\
ATHR & Threshold for angular difference & 30 \\
DTHR & Threshold for linking distance & 20 \\
\hline
\end{tabular}

From the study area and its surroundings, geological structure data samples were obtained in the form of hefty filled with minerals, morphological alignment, veins, \& gash. From each measurement of these structural elements are divided into two components, namely the compression component and the extension component. Stiff, straightness, fracture included in the compression component, while vein, \& gash, included in the extension component. Then for data analysis, the calculation of solid data was performed, to determine the direction of its dominance, then each location of the observation, each rossete and stereonet diagrams were made. This is done to compare the position of the field with the lineaments in the LDA data. Stiffs that are not filled with minerals are assumed to be shear joints, while those filled with minerals (veins) are assumed to be tension joints or release joints.

\section{RESULTS AND DISCUSSION}

\section{Tectonic Setting and General Geology}

Some previous researchers have conducted research on the Southern Mountains region Bemmelen (1949)[5] has examined several geological events that occurred in the Southern Mountains of East Java and made a physiotectonic map regionally. Sartono (1964)[6] was the researcher who first investigated in detail the stratigraphic sequence of the Punung area and the first to provide the names of formations such as the Besole Formation, Jaten Formation, Wuni Formation, Nampol Formation and Punung Formation. Nahrowi et al. (1979)[7] arranged stratigraphic sequences of the Southern Mountains of East Java, covering the area from Pacitan to the Blambangan Peninsula.

Pacitan Regency is physiographically included in the Southern Mountain Range. The rocks that make up the southern mountain range of East Java from old to young are (Samodra, et. al, 1992)[2] : Pre-Tertiary metamorphic rock groups and Eocene Diorite rocks, on top of which are deposited andesit volcanic rocks and sediments in Oligo-Miocene, then covered by Miocene 
limestone, and finally the rocks are partially covered by Quaternary volcanic rocks. Intrusion rocks that break through the southern zone are tonalite, granodiorite and diorite (Oligocene), granodiorite and diorite (Miocene), and andesite and dacite (Mio-Pliocene). The lithostratigraphy which comprise the Pacitan area consists of 3 (three) formations, namely Arjosari Formation (sediment), Mandalika Formation (Oligo-Miocene volcanic) and Watupatok Formation, all of which are interfingering.

East Java region is part of the southeastern Sunda Kraton whose basement is the Cretaceous - Tertiary Melange complex. Regional structural patterns in the form of horizontal fault trending southwest-northeast. This pattern forms a fracture zone that is related to the mineralization formed. The structural patterns of the Pacitan area are: the left horizontal fault pattern, the southwest-northeastern pattern (Grindulu Fault) and the east-west pattern. Whereas in the southern part it is predominantly patterned in the northwest - the south and the northeast - the southwest. The main force north-south uplift the Old Andesite Formation in the Middle Miocene along with strike faults, folds and fractures which are then filled with andesite, dacite, and quartz veins. The reduction in compression energy results in normal faults in the same direction as the development of extention and compression faults. In Plio-Plistocene, tectonic activity occurs again which results in tilting to the south of the existing rock formations. The presence of the Middle Miocene intrusion bodies caused a reorientation of the force that was originally directed from North - South to Northeast-Southwest and gave structural patterns in that direction. The fault was thought to be related to magmatic activity and to control the spread of precious metal and base metal mineralization in the Pacitan and surrounding areas. Symptoms of enlargement resembles the letter ' $V$ ' pattern (Wamilta, G. E, 1998)[8] and is thought to be part of a deep seated fault system.

\section{Lineament Density Analysis}

The Lineament Density Analysis (LDA) process is expected to be able to help interpret existing lineament patterns, which are likely to be formed due to geological structures. Gupta (1991)[9], concluded that the straightness is a form of (1) shear zones/faults; (2) rift valleys; (3) truncation of outcrops; (4) fold axial traces; (5) joint and fracture traces; (6) topographic, vegetation, soil tonal changes alignment. The lineament pattern is divided into positive and negative. Positive line straightness (light straightness pattern) is interpreted as ridge straightness, trough, and crater, while negative line straightness (dark straight line tones) represents muscular, fault, and shift.

Figure 3-6 showed of automatic lineament extraction from shaded relief on sun angel $0^{\circ}, 45^{\circ}$, $90^{\circ}$, and $135^{\circ}$.

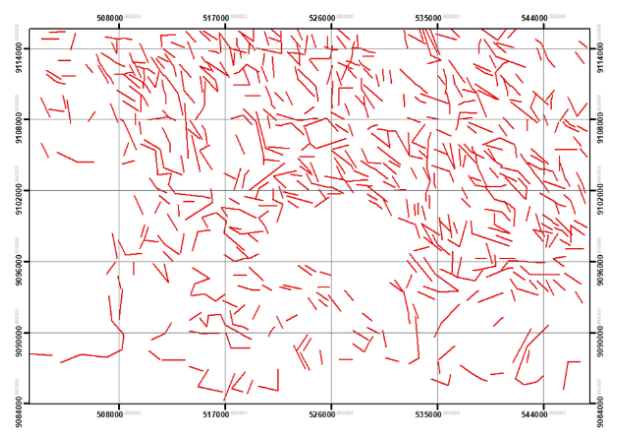

Fig. 3. Results of automatic lineament extraction from shaded relief on sun angel $0^{0}$. 


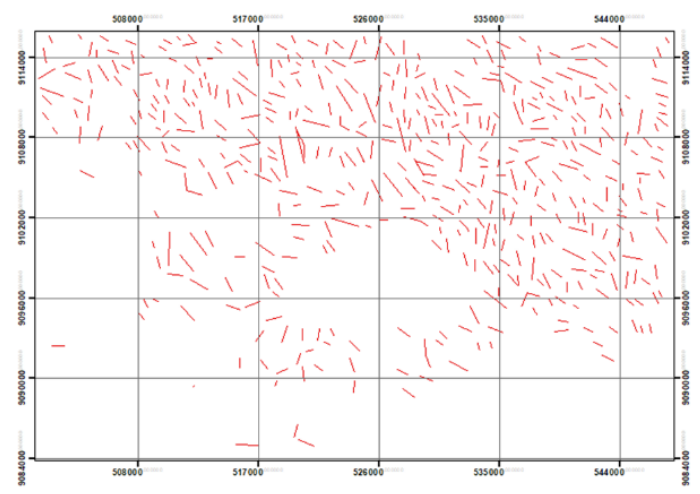

Fig. 4. Results of automatic lineament extraction from shaded relief on sun angel $45^{\circ}$.

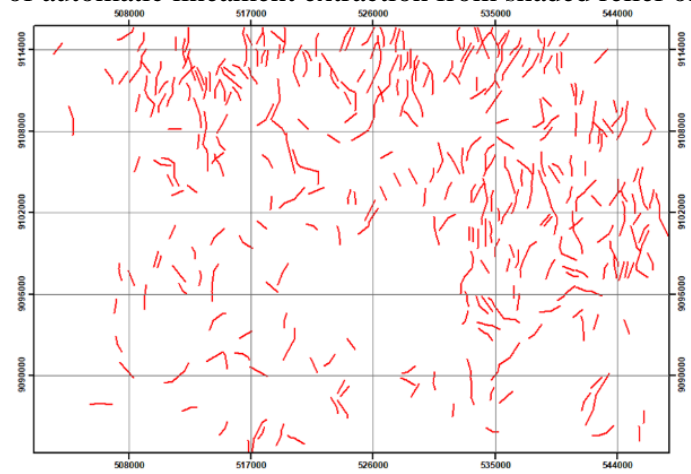

Fig. 5. Results of automatic lineament extraction from shaded relief on sun angel $90^{\circ}$.

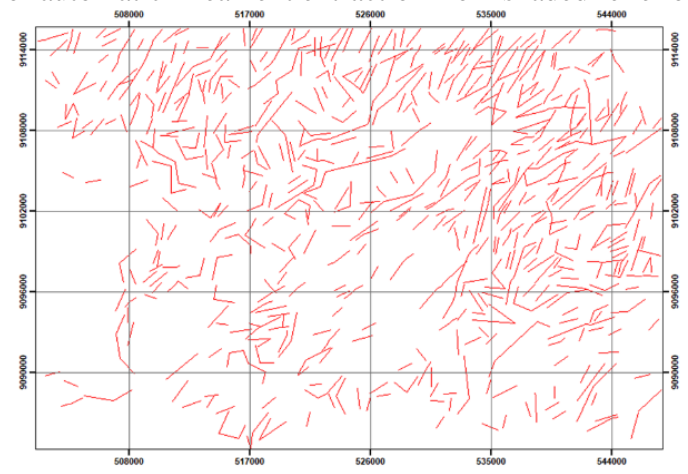

Fig. 6. Results of automatic lineament extraction from shaded relief on sun angel $135^{\circ}$.

Data from the interpretation of the lineaments are plotted into the rose diagram to find out the general direction (trend) of the lineaments. The rose diagram is basically a histogram oriented from an axis to a circle in order to get the actual angular direction (Yasin, A.M, Sukiyah, E, Sulaksana, N, and Isnaniawardhani, V, 2016) [10].

From the results of lineament analysis or lineament at each difference in the irradiation angle, it was found that the dominant direction of the alignment on the lineament density map includes: 
a. On the automatic lineament density map with a combination of shaded relief on sun angel $0^{\circ}$, it has a NW-SE dominant directional orientation (Figure 7).

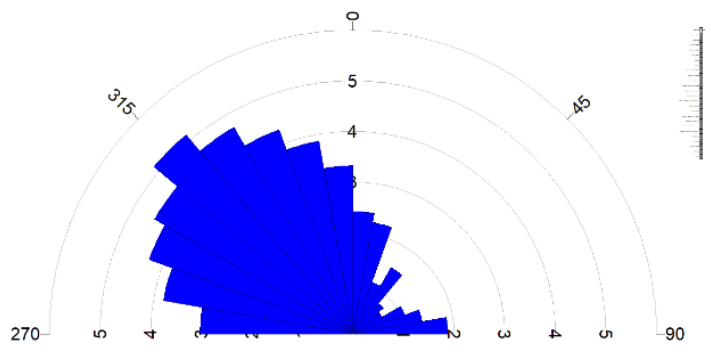

Fig. 7. Rose diagram on sun angel $0^{0}$.

b. On the automatic lineament density map with a combination of shaded relief on the sun angel $45^{\circ}$, it has a NW-SE dominant directional orientation (Figure 8).

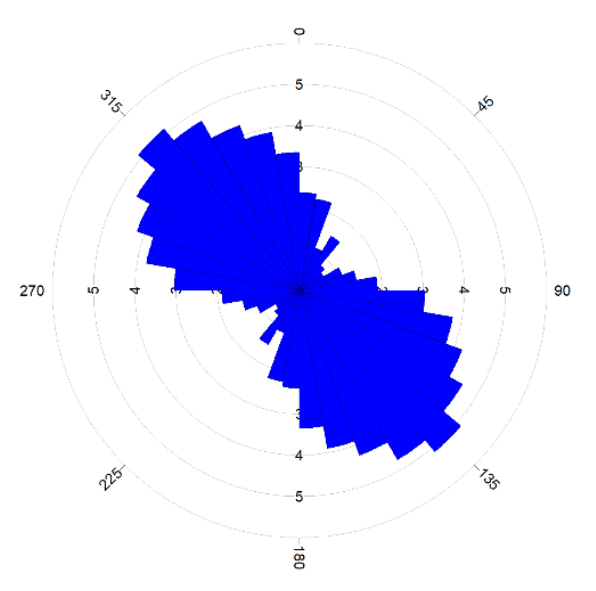

Fig. 8. Rose diagram on sun angel $45^{\circ}$.

c. On the automatic lineament density map with a combination of shaded relief on the sun angel $90^{\circ}$, it has an N-S dominant directional orientation (Figure 9). 


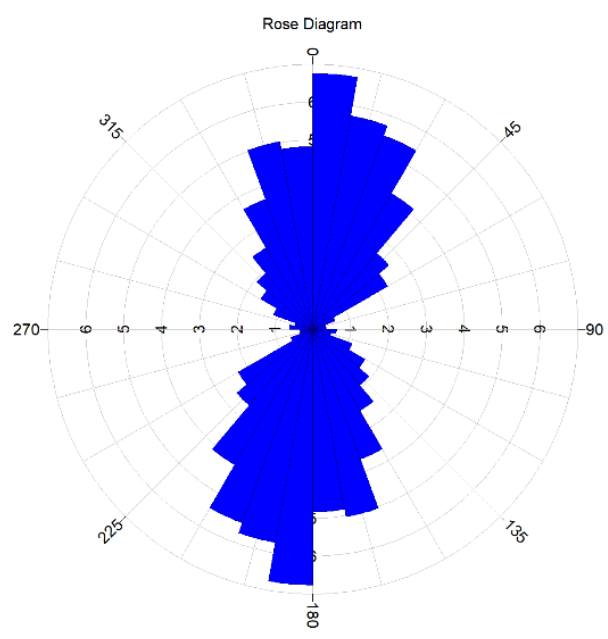

Fig. 9. Rose diagram on sun angel $90^{\circ}$.

On the automatic lineament density map with a combination of shaded relief on the sun angel $135^{\circ}$, it has a NE-SW dominant directional orientation (Figure 10).

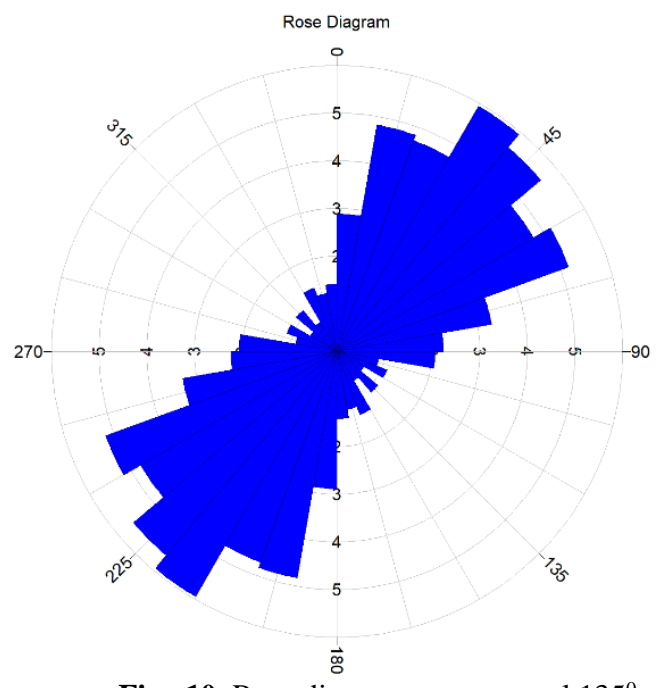

Fig.. 10. Rose diagram on sun angel $135^{\circ}$.

From the dominance of the alignment from each irradiation angle, it can be interpreted that, the direction of the alignment resembles the direction of the regional structure, namely with the direction of the regional structure in the dominant southern region of the northwest - south and northeast - southwest, with the main force north-south direction.

\section{Field Data}

Field data is used as supporting data from making lineament density maps, checking the direction of alignment, and proving the presence of veins or fractures filled with minerals. In 
the study area, 11 stop site were taken, 5 of which were used as the location for collecting fracture data and 6 others as checking whether there were alteration and mineralization zones (Figure 11).

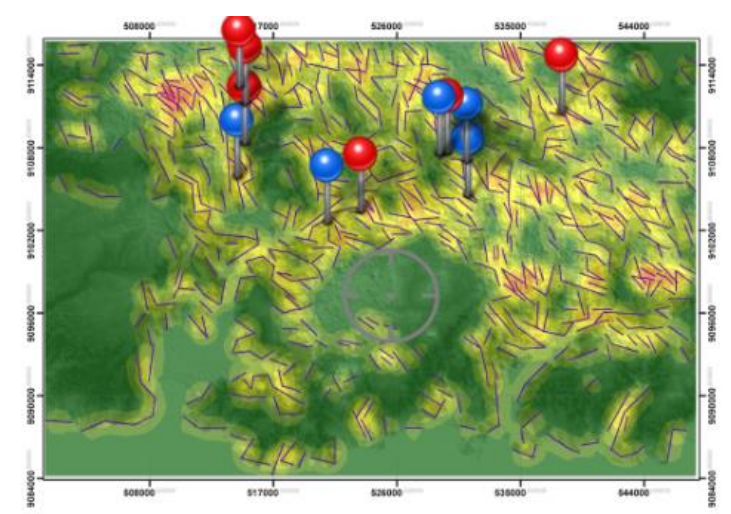

Fig. 11. Location of data collection a. there are alteration and mineralization zones (veins carrying sulfide minerals) - (red) b. There is a clay alteration zone (blue).

Collection 100 gash fracture data at this observation location.

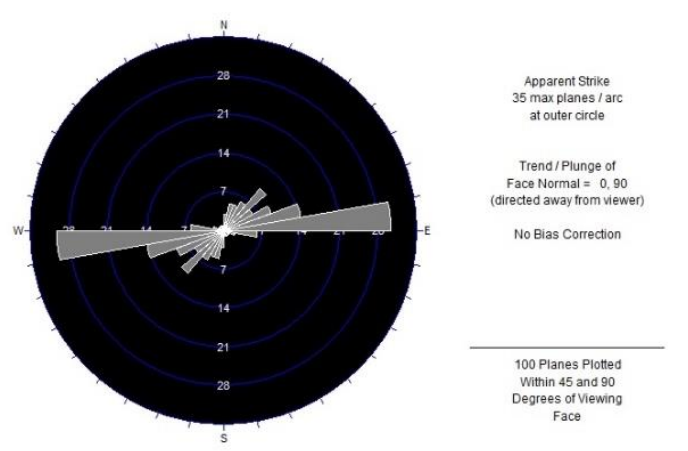

Fig. 12. The rose diagram in the plotting gash fracture data at the first location, with the orientation of the dominant W-E direction, the gash fracture is filled with calcite veins. 


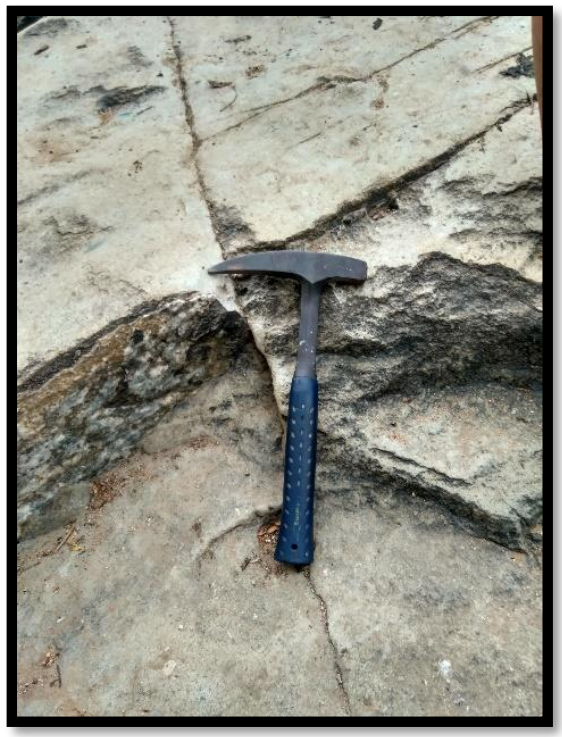

Fig. 13. Calcite vein fills the fracture at the first stop site.
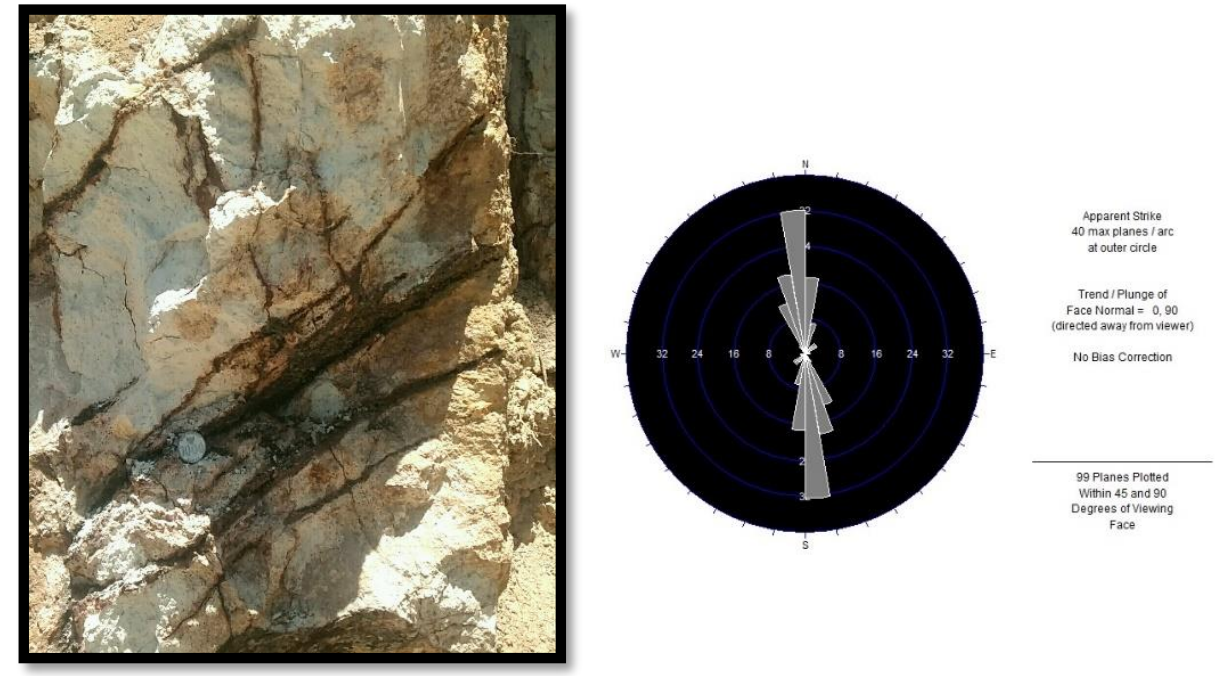

Fig. 14. The Rose Diagram in the gash fracture plotting data at the second stop site, with the dominant orientation $\mathrm{N}-\mathrm{S}$, the gash fracture is filled with quartz veins and sulphide minerals. 


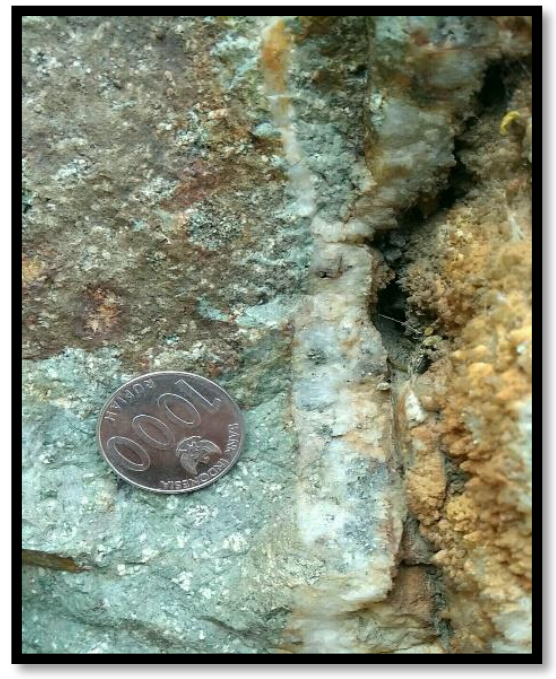

Fig. 15. Quartz vein is filled fracture at the second stop site.

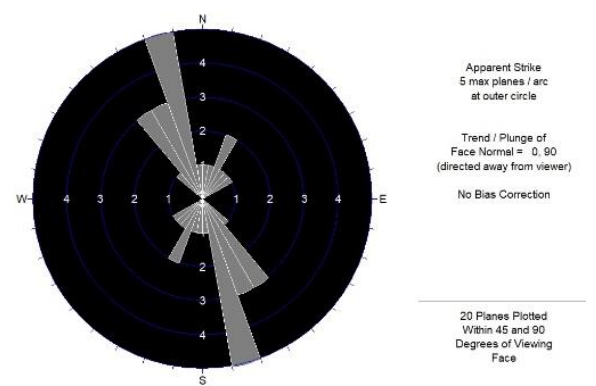

Fig. 16. The rose diagram in the plotting gash fracture data at the third stop site, with the dominant orientation NW-SE, the gash fracture is filled with quartz-oxide veins and sulfide minerals.

Fig. 17. Quartz-oxide vein is filled fracture at the third stop site.

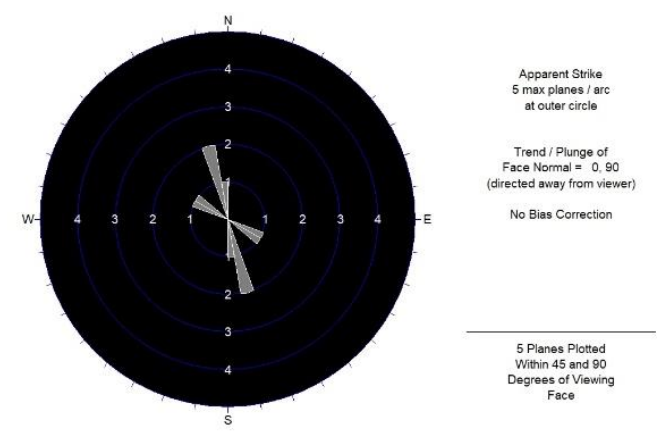

Fig. 18. The rose diagram in the plotting gash fracture data at the fourth stop site, with the dominant orientation NW-SE, the gash fracture is filled with quartz-oxide veins. 


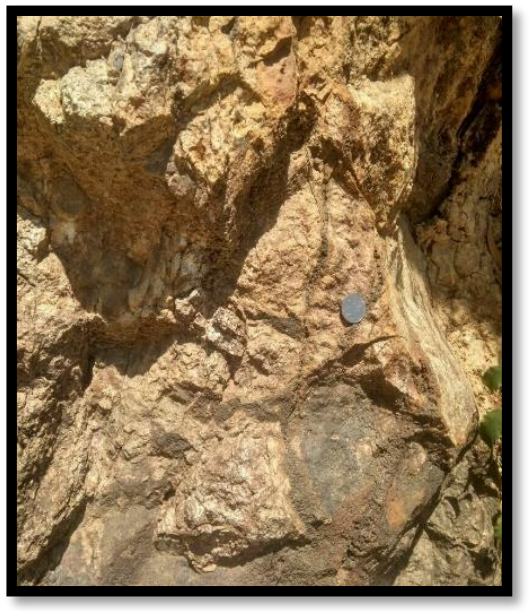

Fig. 19. Quatz-oxide vein is filled fracture at the fourth stop site.

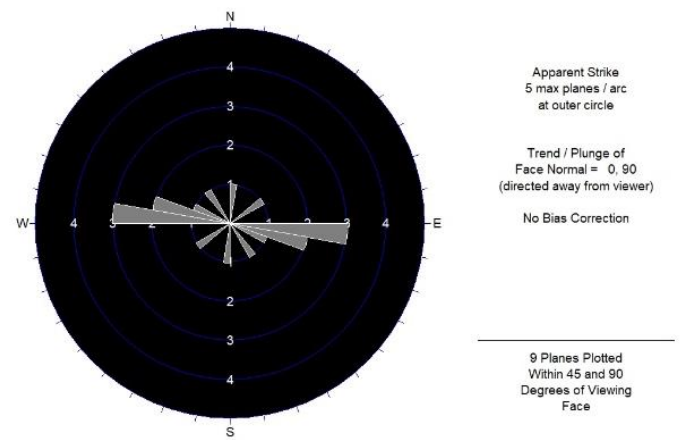

Fig. 20. The rose diagram in the plotting gash fracture data at the fifth stop site, with the dominant orientation W-E, the gash fracture is filled with quartz-oxide veins dan sulfide minerals. 


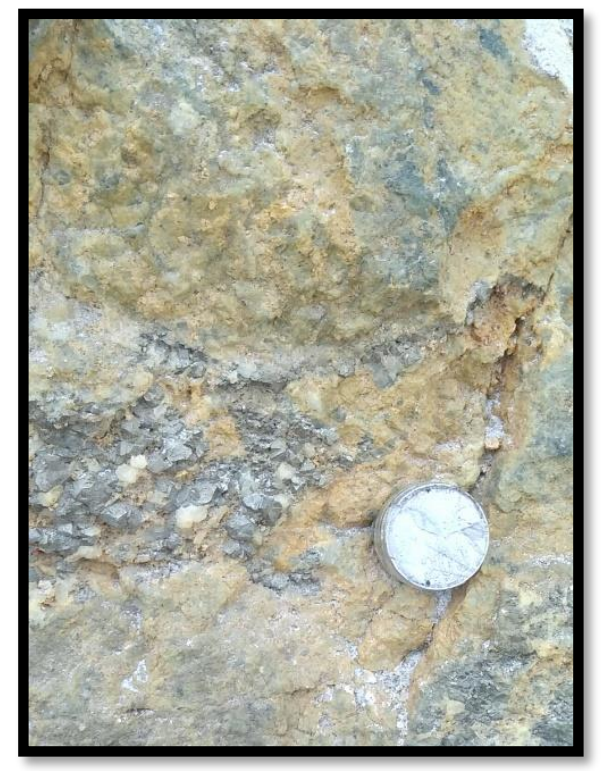

Fig. 21. Quatz-oxide vein is filled fracture at the fifth stop site.

The results of the analysis showed that, high density values were collected dominantly on the northwest and northeast sides, especially the hills in the Tegalombo area, which due to the morphology of this area were clearly visible. In the study area, it is clear that there are differences in density in the southern area of Kasihan village where this indicates a pattern of well-developed alignment, in rocks on the north side, while on the south side the density value decreases. Morphological factors that are controlled by geological and lithological structures greatly affect the density value of each location in the study area. DEM data has a better resolution than satellite imagery, making it suitable for geological analysis (Verdiansyah, Okki, 2019) [11]. This concept described generally that mineralization would exist on devastated areas or had very strong structure intensity (Nugroho, U.C, and Tjahjaningsih A, 2016) [12]. The results of the alignment map analysis that were extracted automatically showed that the direction of the main straightness of the lineament map was NW-SE, N-S, and NE-SW.

From the gash fracture sampling data, the direction of the gash fracture filled by quartz veins carrying sulfide minerals is generally directed towards NW-SE, W-E and N-S. Mapping the alignment associated with the geological structure a very important (Iswahyudi, S, et al, 2014)[13]. The vein directions generally follow regional geological structural patterns.

\section{Conclusion}

The Lineament Density Method is a practical and efficient method for extracting and analyzing geological alignments in large areas with little outcrop (closed area). The combination of straightness extracted automatically with geospatial data (length, density, and trends) can update tectonic settings and determine the geological structure zones, and can further identify alteration zones and mineralization. The results of the alignment map analysis that were extracted automatically and manually showed that the direction of the main straightness of the lineament map was NW-SE, N-S, and NE-SW. The results of the analysis of field data samples 
indicate that the direction of lineaments which are generally in the form of surface vein types are in the direction of NW-SE, N-S, and W-E. LDA application to determine the direction of the structure, is proven to be possible and can be used to accelerate the exploration of mineralization or for other research purposes. 


\section{References}

[1] Herlambang, R.F, and Novranza, Kms, 2016, Pemetaan Kelurusan Menggunakan Remote Sensing dan Korelasinya Terhadap Distribusi Manifestasi Permukaan di Daerah Potensi Geothermal Kepahiang Bengkulu, Prosiding Seminar Nasional Fisika, Fakultas MIPA, Universitas Negeri Jakarta, Vol.V, pp 57-64

[2] Samodra, H., Gafoer, S. dan Tjokrosapoetro, S.,1992. Geologi Lembar Pacitan, Jawa, Pusat Penelitian dan Pengembangan Geologi, Bandung.

[3] Verdiansyah, O., dan Hartono, H.,G.,2018. Aplikasi Lineament Density Analysis Untuk Membatasi Pola Kaldera Purba Godean. Jurnal Teknologi Technoscientia 9 (2).

[4] Abdullah, A., Akhir, J.M., Abdullah, I., (2010), Automatic Mapping of Lineaments Using Shaded Relief Images Derived from Digital Elevation Model (DEMs) in the Maran-Sungi Lembing Area, Malaysia, EJGE Bulletin vol. 15, pp 949 - 957.

[5] Bemmelen, R. W. van, 1949. The Geology of Indonesia, Vol. IA, General Geology, Martinus Nijnhoff, The Hague, Netherlands.

[6] Sartono, S., 1964, Stratigraphic and Sedimentation of The Eastern Mostpart of Gunung Sewu, East Java, Publikasi Teknik Geologi Umum, No.1, Direktorat Geologi Bandung.

[7] Nahrowi, T, Y., 1979, Geologi Pegunungan Selatan Jawa Timur, PPTMGB, Lemigas Cepu, Indonesia.

[8] Wamilta, G. E., 1998. Geologi dan Geokimia Batuan Terobosan Daerah Gunung Lima dan Sekitarnya, Kecamatan Kebonagung, Kabupaten Pacitan, Jawa Timur. Skripsi Tugas Akhir, Institut Teknologi Bandung.

[9] Gupta, R.P., 1991, Remote Sensing Geology, Berlin, Heidelberg: Springer-Verlag.

[10] Yasin, A.M, Sukiyah, E, Sulaksana, N, and Isnaniawardhani, V, 2016, Fenomena Morfotektonik pada Citra SRTM di Wilayah Teluk Kendari, Bulletin of Scientific Contribution, Vol.14, No.2, pp. 163-170.

[11] Verdiansyah, Okki, 2019, A Desktop Study to Determine Mineralization Using Lineament Density Analysis at Kulon Progo Mountains Yogyakarta and Central Java Province, Indonesian Journal og Geography, Vol.51 No.1., pp.31-41.

[12] Nugroho, Udhi C and Tjahjaningsih, Arum, 2016, Lineament Density Information Extraction using DEM SRTM Data to Predict The Mineral Potential Zones, International Journal of Remote Sensing and Earth Sciences, Vol.13 No.1, pp 67-74.

[13] Iswahyudi, S, Saepuloh, A, and Widagdo, A., 2014, Delineating Outflow Zones Using Linear Features Density (LFD) Derived From Landsat Imagery at Paguyangan, Brebes, Central Java, Proceedings, $3^{\text {rd }}$ International ITB Geothermal Workshop. 